\title{
Skin-to-skin contact between mothers and full-term newborns after birth: a cross-sectional study
}

\author{
Contato pele a pele entre mãe e recém-nascido a termo no parto normal: estudo transversal \\ Contacto piel con piel entre madre y recién nacido en el parto normal: estudio transversal
}

Universidade de São Paulo. São Paulo, São Paulo, Brazil. "University of Toronto, The Hospital for Sick Children, Peter Gilgan Centre for Research and Learning. Toronto, Canada.

How to cite this article:

Kuamoto RS, Bueno M, Riesco MLG. Skin-to-skin contact between mothers and full-term newborns after birth: a cross-sectional study. Rev Bras Enferm. 2021;74(Suppl 4):e20200026. doi: http://dx.doi.org/10.1590/0034-7167-2020-0026

\section{Corresponding author: \\ Rosely Sayuri Kuamoto \\ E-mail: rskuamoto@hotmail.com}

EDITOR IN CHIEF: Antonio José de Almeida Filho ASSOCIATE EDITOR: Ana Fátima Fernandes

Submission: $05-01-2020$
Approval: 08-24-2020

\section{ABSTRACT}

Objective: to analyze skin-to-skin contact practice in full-term newborns after birth. Method: a cross-sectional study carried out in São Paulo-SP with 78 mother-child binomials. Data were obtained from medical records and by non-participant observation. Maternal, neonatal and care conditions, length of skin-to-skin contact and breastfeeding attachment were analyzed. Results: skin-to-skin contact was performed in $94.9 \%$ of births, with a mean length of 29 minutes. Births with intact perineum took longer, neonates with Apgar 10, without upper airway aspiration, assisted by a nurse-midwife and with neonatal assistance by a resident in pediatrics. The variables that favor breastfeeding attachment were perineal integrity, newborn with good vitality, without upper airway aspiration and who received professional assistance for breastfeeding attachment. Conclusion: skin-to-skin contact was performed in almost all births, but with less time than recommended as best practice.

Descriptors: Newborn; Mother-Child Relations; Natural Childbirth; Cross-Sectional Studies; Midwifery.

\section{RESUMO}

Objetivo: analisar a prática do contato pele-a-pele em recém-nascidos a termo no parto normal. Método: estudo transversal, realizado em São Paulo-SP, com 78 binômios mãe-filho. Os dados foram obtidos nos prontuários e por observação não participante. Foram analisadas as condições maternas, neonatais e assistenciais, duração do contato pele-a-pele e pega da mama materna. Resultados: o contato pele-a-pele foi realizado em 94,9\% dos nascimentos, com duração média de 29 minutos. A duração foi maior em partos com períneo íntegro, neonatos com Apgar 10, sem aspiração das vias aéreas superiores, assistidos por enfermeira obstétrica e com assistência neonatal por médico residente em pediatria. As variáveis que favorecem a pega da mama foram integridade perineal, neonato com boa vitalidade, sem aspiração das vias aéreas superiores e que receberam ajuda profissional para a pega Conclusão: o contato pele-a-pele foi realizado na quase totalidade dos nascimentos, mas com tempo inferior ao recomendado como boa prática.

Descritores: Recém-Nascido; Relações Mãe-Filho; Parto Normal; Estudos Transversais; Enfermagem Obstétrica.

\section{RESUMEN}

Objetivo: analizar la práctica del contacto piel-a-piel en recién-nacidos a término durante el parto normal. Método: estudio transversal, realizado en São Paulo-SP, con 78 binomios madrehijo. Los datos provienen de historias clínicas y observación no participante. Se analizaron las condiciones maternas, neonatales y del parto, la duración del contacto piel-a-piel y el acople mamario. Resultados: el contacto piel-a-piel se realizó en el $94,9 \%$ de los partos, con duración media de 29 minutos, que fue mayor en partos con perineo intacto, neonatos con Apgar 10, sin aspiración de vía aérea superior, asistidos por enfermera obstétrica y con atención neonatal por médico pediatra residente. Las variables que favorecieron el acople fueron integridad perineal y neonatos con buena vitalidad, sin aspiración de la vía aérea superior, que recibieron ayuda profesional para el acople. Conclusión: el contacto piel-a-piel se realizó en casi todos los partos, con menos tiempo del recomendado como buena práctica. Descriptores: Recién Nacido; Relaciones Madre-Hijo; Parto Normal; Estudios Transversales; Enfermería Obstétrica. 


\section{INTRODUCTION}

Skin-to-skin contact (SSC) consists of positioning newborns (NB) naked and in a prone position, covered only with dry, previouslyheated blankets, on mothers' naked abdomen or chest ${ }^{(1)}$.

Brazilian Ordinance 371/2014 of the Brazilian Ministry of Health $(\mathrm{MoH})^{(1)}$ emphasizes that SSC should be started early: "for all full-term NB, with normal respiratory rhythm, normal tone and without meconium fluid, it is recommended to ensure immediate SSC and continuous after birth". According to the United Nations Children's Fund (UNICEF) ${ }^{(2)}$, professionals who provide obstetric care must provide SSC immediately after birth, allowing it to be performed for at least an uninterrupted hour. The $\mathrm{MoH}$, by the same ordinance, also reinforces that routine procedures performed with neonates can be postponed until after the first hour of life ${ }^{(1)}$.

The Baby-Friendly Hospital Initiative (BFHI), after proposing the "Ten Steps to Successful Breastfeeding (BF)", included, in its fourth step, carrying out SSC after birth ${ }^{(2)}$. According to the $\mathrm{MoH}^{(1)}$, BFHI's fourth step should be interpreted as "placing NB in SSC with their mothers, immediately after birth, for at least one hour, and encouraging mothers to identify whether NB show signs of being wanting to be breastfed, offering assistance if needed".

The scientific literature describes numerous benefits of SSC, when performed immediately after birth. Specifically for NB, promotion of better physiological stability, early onset and longer length of breastfeeding, maternal bond strengthening, higher blood glucose levels, better temperature control, cardiorespiratory stability, shorter crying time, and lower cortisol concentration stand out (stress level) ${ }^{(3-7)}$.

Studies indicate that length of stay of NB in SSC varies, so that each of these benefits is achieved. For better physiological stability, SSC should last about 60 minutes ${ }^{(6)}$, which is similar to the time needed to encourage $\mathrm{BF}$ and to promote maternal and child bond ( 55 minutes of SSC) ${ }^{(6-8)}$. The 60 -minute period is also considered ideal for stabilizing blood glucose levels in $\mathrm{NB}^{(6)}$ and for promoting more stable neonatal behaviors ${ }^{(6-8)}$. Fifteen-minute periods are considered sufficient to promote temperature control and cardiorespiratory stability ${ }^{(6)}$, and staying in SSC for 30 minutes favors reducing crying time ${ }^{(6-7)}$. Therefore, it is noticed that the length of SSC recommended after birth also influences its benefits.

Hospitals with the Baby-Friendly Hospital seal (BFH) were monitored for the first time in 2003, with a view to implementing a periodic assessment system for accredited institutions. A total of 137 institutions have been assessed, which corresponded to $90 \%$ of the total of $152 \mathrm{BFH}$ in Brazil. Compliance with the fourth step was reported in $96 \%$ of all institutions, considering only the categorical assessment (performed or not performed) ${ }^{(9)}$. In contrast, a retrospective descriptive study on SSC prevalence within NB's first hour of life in a BFH in the city of Marilia, countryside of São Paulo, investigated 1,787 birth records, and reported that only $7 \%$ of NB received SSC within of the first 30 minutes of life and $24 \%$ within the first hour ${ }^{(10)}$.

Likewise, data from "Nascer no Brasil" (freely translated as Born in Brazil) showed insufficient rates of SSC after birth. This is a hospital-based study involving 266 maternity hospitals in 190 different municipalities in the country, including 23,940 women from February 2011 to October 2012. SSC achievement rates after birth were found to be $27.9 \%$ in northern, $28.8 \%$ in northeastern, $26.9 \%$ in southeastern, $32.5 \%$ in southern and $25.5 \%$ in center-western
Brazil. Concerning BF in delivery rooms, rates were even lower, varying between $11.5 \%$ in northeastern and $22.4 \%$ in southern Brazil. Regarding the investigated institutions that had the BFH seal, only $38.1 \%$ of mothers and children were positioned in SSC after birth, and $24 \%$ of neonates were breastfed in delivery rooms ${ }^{(11)}$.

A cross-sectional study conducted in six countries in Latin America assessed SSC categorically (performed/not performed). SSC was identified in 97\% of births in Argentina, 95\% in Peru, 91\% in Brazil, $75 \%$ in Chile, $64 \%$ in the Dominican Republic and $58 \%$ in Uruguay. BF rates were $97 \%$ in Argentina, $88 \%$ in Peru, $79 \%$ in Brazil, $62 \%$ in Chile, $51 \%$ in Uruguay and $46 \%$ in the Dominican Republic ${ }^{(12)}$. The variation in these findings may indicate differences in interpretation of SSC practice and in maternal and child care guidelines.

A qualitative study carried out in India aimed to identify the barriers to implement SSC in hospitals. Numerous barriers were described by healthcare professionals, highlighting the space and reduced number of employees available in delivery rooms to perform SSC, hospital routine of assessments that require departmental change, concern of the team due to lack of knowledge of practice and parochialism about SSC ${ }^{(13)}$.

Creating institutional policies and protocols for SSC implementation after birth is important for its practice. Financing and BFHI certification are other items that contribute to its effectiveness ${ }^{(14)}$. Considering the evidence on benefits of SSC and its insufficient or inadequate performance in health services, we sought to study SSC practice after birth in a BFH, following the maternal and child care guidelines recommendations, in order to contribute to its expansion in Brazil.

\section{OBJECTIVE}

This study aims to analyze SSC performed on full-term NB after natural birth. The specific objectives were to determine the rates of SSC performed immediately after birth; verify the time spent by NB in SSC after birth; analyze the factors related to Length of SSC after birth; analyze breastfeeding attachment within NB's first hour of life.

\section{METHODS}

\section{Ethical aspects}

The project was approved by the Research Ethics Committees of Universidade de São Paulo School of Nursing and the institution where data were collected. Participants were informed about the voluntary and anonymous nature of their participation. When they agreed to be included, they were asked to sign the Informed Consent Form (ICF). If a participant was under 18 years old, a legal guardian was required to sign the Assent Term, in addition to ICF. Written consent was also obtained from all professionals directly involved in data collection (nurses and physicians).

\section{Design, period, and study site}

This is a cross-sectional observational study guided by STROBE (Strengthening the Reporting of Observational Studies in Epidemiology), carried out at a general hospital based in southern 
São Paulo, SP, with a monthly mean of 400 births per month, of which $60 \%$ are natural births. In 2005 the place was accredited by $\mathrm{BFHI}$ and maintained the seal until data collection ended. The obstetric center (OC) has PPP beds (pre-delivery, delivery and post-delivery) and a neonatal resuscitation room, where routine care procedures for NB are performed. Natural births are attended by nurse-midwives, midwives, obstetricians, resident in pediatrics and students of nursing, midwifery and medicine. Data were collected from 1 to 31 August 2017.

\section{Population and sample}

The population comprised postpartum women and their full-term, healthy NB, born by natural birth in the study field. Based on the monthly mean of natural births at the study site, the representative sample of prevalence was composed of 78 binomials, using the following formula:

$$
\mathrm{n}=\frac{p(1-p) \mathrm{Z}_{a / 2}^{2}}{\mathrm{e}^{2}}
$$

$\mathrm{N}$ represents the sample size; $z$ represents the standard score for a probabilistic error of $5 \%(z 2.5 \%=1.96$ and $a=5 \%)$; $p$ represents the estimated prevalence $(p=0.5) ; \epsilon$ represents the sampling error margin of $10 \%(\epsilon=0.1)$. The confidence interval adopted was $95 \%$.

In order to ensure the sample's representativeness in relation to practices adopted by professionals from different work shifts, data collection was carried out at different times. To this end, the sample was stratified into four groups according to time of birth in the 24-hour period (day shift 7 a.m. to 7 p.m. and night shift 7 p.m. to 7 a.m./odd shift 7 a.m. to 7 p.m. and night shift 7 p.m. to 7 a.m.).

Women in labor admitted to the OC during the data collection period who had a single pregnancy of full-term NB, with gestational age between 37 and 42 weeks, women in labor without previous indication for cesarean section have been included. Women who underwent cesarean section or forceps, with NB clinically not eligible for SSC (respiratory or hemodynamic instability, muscular hypotonia, vomiting or regurgitation, artificial oxygenation or any other neonatal event that contraindicates early SSC), who presented maternal complications, such as atony uterine, postpartum hemorrhage, placental retention, laceration of the path with continuous bleeding, coagulopathy, among others, have been excluded.

\section{Study protocol}

Data collection was performed by one of the researchers, the first author of this study.

Before data collection started, professionals who provide obstetric and neonatal care were informed about the study objectives and data collection procedures. Women in labor were approached by the researcher at admission to the OC and were also clarified about data collection objectives and procedures.

Data on maternal and neonatal characterization and obstetric care (maternal age, parity, NB's sex, Apgar (first and fifth minutes), perineal condition, presence of a companion, professional who assisted childbirth) were obtained from medical records. Those related to SSC and neonatal care were obtained through non-participant observation, initiated in the expulsive period of childbirth.
To record data, an instrument designed exclusively for this study was used. SSC was recorded as "yes or no" and its length was counted in minutes (assessed by a digital timer). The onset of SSC after birth was computed from the position of NB on their mothers' chest or abdomen (digital timer started) and considered interrupted at the moment when NB were taken from their mothers' lap (digital timer stopped). It was also recorded which professional was responsible for neonatal care, whether upper airways (UA) were aspirated and which routine care was performed with NB within the first hour of life (prophylaxis of neonatal ophthalmia with silver nitrate instillation, digestive hemorrhage with vitamin $\mathrm{K}$ via IM, screening for eye changes by red reflex test and weighing).

Neonatal care, in some cases, was performed in SSC, without interrupting this practice within the first hour of life. When an interruption occurred before the recommended 60 minutes, neonatal care was provided in the resuscitation room. Thus, it was necessary to follow NB to this room uninterruptedly, following them up until they returned to their mothers, continuing with observation throughout the first hour of life.

It was also verified whether or not effective breastfeeding attachment occurred within NB's first hour of life. Breastfeeding attachment was considered effective when there was apprehension of the maternal nipple-areolar region by the NB. Nursing professionals' assistance in positioning NB on their mothers' breasts was performed spontaneously by a professional or at mothers' request.

During data collection, there was no intervention by the researcher in the assistance provided to mothers and children.

\section{Analysis of results, and statistics}

Descriptive analyzes were performed, with absolute and relative frequency, mean, standard deviation (SD), minimum and maximum, and inferential analysis, using the SPSS programs, version 22.0 and $\mathrm{R}$, version 3.4.2.

Pearson's chi-square and Fisher's exact tests were used to analyze categorical variables. Kruskal-Wallis and U-Mann-Whitney tests were used to compare the numerical variables' means. To analyze the association among numerical variables (SSC time and maternal age), Spearman's correlation was performed, with a correlation ranging from -1 to 1 , and zero equates to no relationship among variables.

Logistic regression with variable selection via Lasso (Least Absolute Shrinkage and Selection Operator) was used to analyze Length of SSC.

The Lasso method selects the most significant variables for a given outcome using the cross-validation method. According to the variables of interest in the study, the program performs several regressions with different values of penalty parameters to carry out analysis. The level of significance established was 5\%.

\section{RESULTS}

During the data collection period, 453 NB were born, with 301 natural births, 151 cesarean sections and a forceps.

Seventy-eight mother-child binomials have been included in this study (40 births on day shift and 38 on night shift). Among 
the 79 women who met the inclusion criteria and accepted to participate in the research, only one was excluded due to instrumental outcome of childbirth.

Mothers' age ranged from 13 to 42 years; most (55.2\%) were up to 25 years old (mean=24.9; SD=5.9) and 44.8\% were primiparous. During labor (LB), oxytocin administration was the most frequent intervention (51.5\%). Episiotomy was performed in $12.8 \%$ of women, and $74.4 \%$ had perineal lacerations. Most women (83.3\%) were accompanied by a partner or a family member and $51.2 \%$ of births were attended by nurse-midwives (data not shown in table).

Regarding NB's characteristics, 59\% were female, all had good vitality after birth (Apgar $\geq 7$ in the first and fifth minutes) and most (61.6\%) weighed between 3,000 and 3,495 grams (mean=3,195; $\mathrm{SD}=335.2$ ). $\mathrm{UA}$ was performed in $17.9 \%$ of NB, who, in most cases, received the first routine care (silver nitrate and vitamin Kadministration, red reflex test and weighing) during the first hour of life. It was observed that $64.1 \%$ of NB started breastfeeding within the first hour of life, and $67.9 \%$ received assistance from a professional (voluntarily or by request) to perform correct breastfeeding attachment. A pediatrician or resident in pediatrics was present in all births and provided neonatal care in the OC (data not shown in table).

Regarding SSC, $94.9 \%$ of mothers and children performed this practice after birth and $73 \%$ of these were separated before 60 minutes. SSC lasted a mean of 29 minutes (SD=23.7). The reason for not performing SSC in four (5.1\%) mothers and children was due to immediate transfer of NB by a professional to the neonatal resuscitation room in order to perform the first routine care.

Table 1 presents a bivariate analysis of Length of SSC. There was a significant association with a longer length in relation to the following variables: perineal condition (woman with intact perineum; $p=0.022)$; births attended by nurse-midwives $(p=0.027)$; Apgar score in the fifth minute with index $10(p=0.003)$; NB without UA ( $p>0.001)$; NB without routine care within the first hour ( $p>0.001)$; neonatal care provided by a pediatric resident physician $(p=0.028)$.

A bivariate analysis of length of SSC in relation to maternal age and NB weight, carried out by Spearman's correlation, showed no significant difference (data not shown in table).

Figure 1 shows the relationship between Length of SSC less than 60 minutes and UA in NB. By LASSO regression analysis, it is observed that the NB who received UA were, on mean, 27 minutes less in SSC after birth.

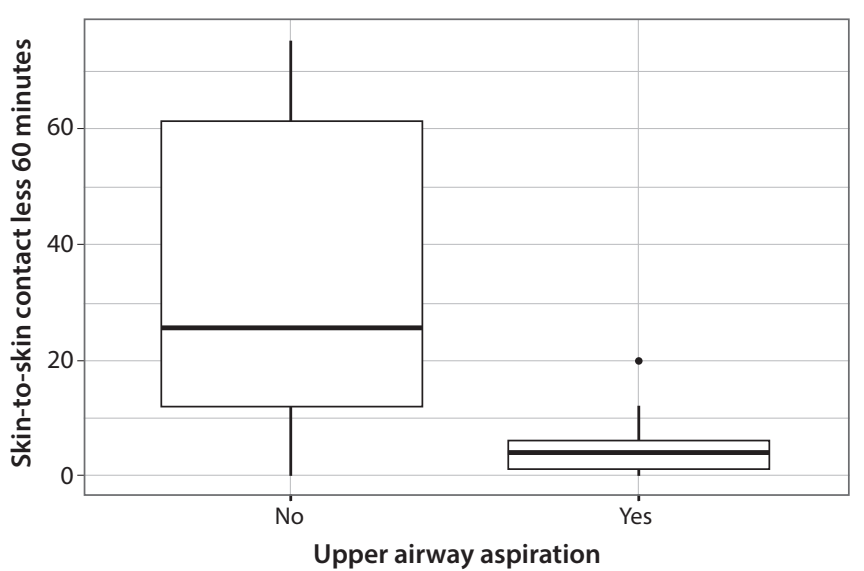

Figure 1 - Skin-to-skin contact less than 60 minutes in relation to upper airway aspiration, São Paulo, São Paulo, Brazil, 2017

Table 2 shows a bivariate analysis of breastfeeding attachment within NB's first hour of life. There was a significant association 
with a higher proportion of effective breastfeeding attachment in relation to the following variables: higher Apgar score in the first and fifth minutes ( $p=0.035$ and $p=0.009$. Respectively); without UA $(p=0.015)$; professional assistance for breastfeeding attachment $(p<0.001)$. Maternal perineal condition with integrity showed a tendency for breastfeeding attachment to take effect $(p=0.053)$.

A bivariate analysis of length of SSC in relation to maternal age and NB weight, performed by Mann-Whitney test, showed no significant difference (data not shown in table).

Table 2 - Breastfeeding attachment within newborns' first hour of life and $p$ value, São Paulo, São Paulo, Brazil, 2017 (N=78)

\begin{tabular}{|c|c|c|c|c|c|}
\hline \multirow{3}{*}{ Variables } & \multicolumn{4}{|c|}{$\begin{array}{l}\text { Breastfeeding attachment } \\
\text { within the first }\end{array}$} & \multirow{3}{*}{$\begin{array}{c}p \\
\text { value }\end{array}$} \\
\hline & \multicolumn{2}{|c|}{ Yes } & \multicolumn{2}{|c|}{ No } & \\
\hline & $\mathbf{n}$ & $\%$ & $\mathbf{n}$ & $\%$ & \\
\hline \multicolumn{6}{|l|}{ Parity } \\
\hline Primiparous & 22 & 62.9 & 13 & 37.1 & \multirow{4}{*}{$1.000^{*}$} \\
\hline Secondiparous & 15 & 62.5 & 9 & 37.5 & \\
\hline Third parous & 6 & 66.7 & 3 & 33.3 & \\
\hline Multiparous & 8 & 80.0 & 2 & 20.0 & \\
\hline \multicolumn{6}{|l|}{ Sex } \\
\hline Female & 33 & 71.7 & 13 & 28.3 & \multirow{2}{*}{$0.092 \dagger$} \\
\hline Male & 17 & 53.1 & 15 & 46.9 & \\
\hline \multicolumn{6}{|l|}{ Apgar (first minute) } \\
\hline 7 & - & - & 1 & 100.0 & \multirow{3}{*}{$0.035^{*}$} \\
\hline 8 & 3 & 33.3 & 6 & 66.7 & \\
\hline 9 & 47 & 69.1 & 21 & 30.9 & \\
\hline \multicolumn{6}{|l|}{ Apgar (fifth minute) } \\
\hline 8 & - & - & 1 & 100.0 & \multirow{3}{*}{$0.009^{*}$} \\
\hline 9 & 2 & 25.0 & 6 & 75.0 & \\
\hline 10 & 48 & 69.6 & 21 & 30.3 & \\
\hline \multicolumn{6}{|l|}{ Perineal condition } \\
\hline (1)Laceration & 39 & 67.2 & 19 & 32.8 & \multirow{3}{*}{$0.053^{*}$} \\
\hline Intact & 8 & 80.0 & 2 & 20.0 & \\
\hline Episiotomy & 3 & 30.0 & 7 & 70.0 & \\
\hline \multicolumn{6}{|l|}{ Companion } \\
\hline Yes & 40 & 61.5 & 25 & 38.5 & \multirow{2}{*}{$0.357^{*}$} \\
\hline No & 10 & 76.9 & 3 & 23.1 & \\
\hline \multicolumn{6}{|c|}{ Professional who assisted childbirth } \\
\hline Nurse-midwife & 22 & 71.0 & 9 & 29.0 & \multirow{4}{*}{$0.434^{*}$} \\
\hline Resident in obstetrics & 17 & 68.0 & 8 & 32.0 & \\
\hline Midwifery student & 6 & 46.2 & 7 & 53.8 & \\
\hline Obstetrician & 5 & 55.6 & 4 & 44.4 & \\
\hline \multicolumn{6}{|l|}{ Upper airway aspiration } \\
\hline Yes & 5 & 35.7 & 9 & 64.3 & \multirow{2}{*}{$0.015+$} \\
\hline No & 45 & 70.3 & 19 & 2.7 & \\
\hline \multicolumn{6}{|c|}{ Neonatal care within the first hour } \\
\hline Yes & 14 & 70.0 & 6 & 30.0 & \multirow{2}{*}{$0.713+$} \\
\hline No & 36 & 62.1 & 22 & 37.9 & \\
\hline \multicolumn{6}{|c|}{$\begin{array}{l}\text { Professional assistance in first } \\
\text { breastfeeding attachment }\end{array}$} \\
\hline Yes & 45 & 84.9 & 8 & 15.1 & \multirow{2}{*}{$<0.001 \dagger$} \\
\hline No & 5 & 20.0 & 20 & 80.0 & \\
\hline $\begin{array}{l}\text { Professional responsible } \\
\text { neonatal care }\end{array}$ & & & & & \\
\hline Pediatrician & 38 & 67.9 & 18 & 32.1 & \\
\hline Resident in pediatrics & 12 & 54.5 & 10 & 45.5 & $0.270 \dagger$ \\
\hline
\end{tabular}

\section{DISCUSSION}

In a study that included 1,200 mother-child binomials, SSC after birth was performed by $100 \%$ all of them ${ }^{(15)}$, contrary to this study, in which SSC after birth was performed by $94.9 \%$. Most NB in this study did not remain in SSC for the recommended time of 60 minutes. Although the prevalence of $91 \%$ of SSC in Brazil, found in a multicenter study ${ }^{(12)}$, is close to that obtained in this study, it is worth mentioning that the referred research only included three hospitals in the city of São Paulo and did not assess length of SSC.

The proportion of $27 \%$ of binomials that remained in SSC uninterrupted in this study, as well as the mean Length of SSC (29 minutes), can be considered insufficient, given the benefits for the maternal and child health promotion evidenced by systematic review ${ }^{(3,6)}$.

In this study, the lower availability of pediatric physicians to remain in the $\mathrm{OC}$ (assistance concomitant with the neonatal unit), in comparison to pediatric resident physicians, may be related to a shorter Length of SSC when they were responsible for assistance. Supporting findings from other studies ${ }^{(16-17)}$ that show that professionals can influence length of SSC, also in births attended by nurse-midwives, NB remained, on mean, 17.7 minutes longer in SSC, compared to births attended by physicians obstetricians.

There were no barriers to the onset of SSC in this study; most professionals offered contact after birth and no postpartum woman refused. However, in most cases, SSC was interrupted before the recommended time of one hour, mainly for routine neonatal care, especially UA. It is worth reiterating that the profile of the sample consisted of full-term, healthy NB, without complications that would make it impossible to perform SSC. The results show that aspirated NB are, on mean, 27 minutes less in SSC. A study derived from the research "Born in Brazil" identified UA rates after birth in $71 \%$ of healthy $\mathrm{NB}^{(11)}$, pointing out routine interventions as a barrier to SSC and onset of $\mathrm{BF}^{(18)}$.

Regarding the perineal condition in births without trauma, there was a longer length of SSC and effective breastfeeding attachment in the first hour of life. A systematic review carried out on the performance of perineal suture after birth showed that pain can result in discomfort and impair the mobility of postpartum women, compromising early onset of $\mathrm{BF}^{(19)}$. A study that evaluated 92 binomials in SSC and in conventional care (SSC only after episiorraphy) indicates the importance of SSC after birth for the longest possible time, to favor early BF, suggesting that NB should be kept in SSC uninterruptedly, including during perineal repair ${ }^{(20)}$.

Among the barriers to SSC, an Indian study points out lack of time and adherence as an influence for inadequate implementation of this practice ${ }^{(13)}$, interfering with the proposed benefits. SSC performed for 60 minutes also stimulates oxytocin production, favoring support and contributing to effective breastfeeding attachment (early onset of BF) ${ }^{(21-22)}$.

Although this study has not shown a significant association between length of SSC and effective breastfeeding attachment, early contact is related to effective $\mathrm{BF}^{(16,21-22)}$. Affective bonds are stronger within NB's first two hours of life, and promoting 
maternal bonding at this time is of paramount importance for the effectiveness and maintenance of exclusive breastfeeding ${ }^{(5)}$.

Breastfeeding attachment, within NB's first hour of life, was performed in $64.1 \%$ of the sample. This rate is lower than that obtained in three hospitals in São Paulo, $79 \%^{(12)}$, but above the $16.1 \%$ identified in a national sample representing 266 Brazilian hospitals ${ }^{(11)}$. It should be emphasized that professional assistance contributes to breastfeeding attachment effectiveness, and the nursing team play a fundamental role in this process ${ }^{(16)}$.

The findings of this study suggest a positive influence of BFHI to promote SSC after birth and early onset of BF, with effective rates of breastfeeding attachment within NB's first hour of life.

\section{Study limitations}

The main limitation refers to a possible interference of the researcher in data collection, due to SSC non-participant observation. It is possible that a high percentage of SSC was influenced by the researcher presence in the place.

\section{Contributions to nursing, health, and public policies}

The results of this study pointed out the relevance of nursing in assisting women and NB in childbirth for overcoming the barriers of SSC. The success of SSC depends mainly on nurses', midwives' and physicians' work, in addition to well-established care protocols and institutional policies.

Best practices, such as perineal integrity promotion, routine practice restriction in neonatal care that interfere with SSC and nursing staff availability to support the first feeding are essential for the success of SSC (one hour uninterrupted since birth). To improve this practice, we should emphasize that it is important to record length of SSC, and not exclusively the "yes or no" dichotomous information.

\section{CONCLUSION}

SSC was performed in almost all births, but in less than an hour in most cases. The factors that facilitate SSC prolongation and breastfeeding attachment effectiveness are related to good vitality after birth and perineal integrity. Childbirth assistance by nurse-midwives favored SSC. Professional assistance in breastfeeding attachment favors early breastfeeding, regardless of Length of SSC. The barriers to SSC and breastfeeding attachment effectiveness are related to the routine neonatal care provided to NB during their first hour of life, especially UA.

\section{FUNDING}

Coordination for the Improvement of Higher Education Personnel (CAPES).

\section{REFERENCES}

1. Ministério da Saúde (BR). Portaria n 371, de 07 de maio de 2014. Institui diretrizes para a organização da atenção integral e humanizada ao recém-nascido (RN) no Sistema Único de Saúde (SUS) [Internet]. Diário Oficial da República Federativa do Brasil, 8 maio de 2014. Brasília; 2014[cited 2017 Dec 3]. Seção 1, p.50. Available from: http://bvsms.saude.gov.br/bvs/saudelegis/sas/2014/prt0371_07_05_2014.html

2. Fundo das Nações Unidas para a Infância (UNICEF). Organização Mundial da Saúde. Iniciativa Hospital Amigo da Criança: revista, atualizada e ampliada para o cuidado integrado: módulo 3: promovendo e incentivando a amamentação em um Hospital Amigo da Criança: curso de 20 horas para equipes de maternidade. Brasília: Editora do Ministério da Saúde; 2009.

3. Cleveland L, Hill CM, Pulse WS, DiCioccio HC, Field T, White-Traut R. Systematic review of skin-to-skin care for full-term, healthy newborns. JOGNN. 2017;46(6):857-69. https://doi.org/10.1016/j.jogn.2017.08.005

4. Hakala M, Kaakinen P, Kääriäinen M, Bloigu R, Hannula L, Elo S. The realization of BFHI step 4 in Finland: initial breastfeeding and skin-to-skin contact according to mothers and midwives. Midwifery. 2017;50:27-35. https://doi.org/10.1016/j.midw.2017.03.010

5. Beijers R, Cillessen L, Zijlmans MA. An experimental study on mother-infant skin-to-skin contact in full-terms. Infant Behav Dev. 2016;43:5865. https://doi.org/10.1016/j.infbeh.2016.01.001

6. Moore ER, Bergman N, Anderson GC, Medley N. Early skin-to-skin contact for mothers and their healthy newborn infants. Cochrane Database Syst Rev. 2016;11:CD003519. https://doi.org/10.1002/14651858.CD003519.pub4

7. Stevens J, Schmied V, Burns E, Dahlen H. Immediate or early skin-to-skin contact after a caesarean section: a review of the literature. Matern Child Nutr. 2014;10(4):456-73. https://doi.org/10.1111/mcn.12128

8. Dani C, Cecchi A, Commare A, Rapisardi G, Breschi R, Pratesi S. Behavior of the newborn during skin-to-skin. J Hum Lact. 2015;31(3):452-7. https://doi.org/10.1177/0890334414566238

9. Araújo MFM, Otto AFN, Schmitz BAS. First assessment of the "Ten Steps for the Maternal Breast-Feeding Success" compliance in BabyFriendly Hospitals in Brazil. Rev Bras Saúde Mater Infant. 2003;3(4):411-9. https://doi.org/10.1590/S1519-38292003000400006

10. Siqueira FPC, Colli M. Prevalence of early contact between mother and newborn in a hospital child friend. Rev Enferm UFPE[Internet]. 2013 [cited 2017 Dec 3];7(11):6455-61. Available from: https://periodicos.ufpe.br/revistas/revistaenfermagem/article/view/12292/14958

11. Moreira MEL, Gama SGND, Pereira APE, Silva AAMD, Lansky S, Pinheiro RDS. Clinical practices in the hospital care of healthy newborn infant in Brazil. Cad Saúde Pública. 2014;30(1):S128-S139. https://doi.org/10.1590/0102-311x00145213

12. Binfa L, Pantoja L, Ortiz J, Cavada G, Schindler P, Burgos RY, et al. Midwifery practice and maternity services: a multisite descriptive study in Latin America and the Caribbean. Midwifery. 2016;40:218-25. https://doi.org/10.1016/j.midw.2016.07.010 
13. Alenchery AJ, Thoppil J, Britto CD, de Onis JV, Fernandez L, Suman Rao PN. Barriers and enablers to skin-to-skin contact at birth in healthy neonates: a qualitative study. BMC Pediatrics. 2018;18(1). https://doi.org/10.1186/s12887-018-1033-y

14. Hubbard JM, Gattman KR. Parent-infant skin-to-skin contact following birth: history, benefits, and challenges. Neonatal Netw. 2017;36(2):8997. https://doi.org/10.1891/0730-0832.36.2.89

15. Allen DJ, Parratt JA, Rolfe MI, Hastie CR, Saxton A, Fahy KM. Immediate, uninterrupted skin-to-skin contact and breastfeeding after birth: a cross-sectional electronic survey. Midwifery. 2019;79:102535. https://doi.org/10.1016/j.midw.2019.102535

16. Abdulghani N, Edvardsson K, Amir LH. Health care providers' perception of facilitators and barriers for the practice of skin-to-skin contact in Saudi Arabia: a qualitative study. Midwifery. 2019;81:102577. https://doi.org/10.1016/j.midw.2019.102577

17. Robiquet $P$, Zamiara PE, Rakza T, Deruelle F, Mestdagh B, Blondel G, et al. Observation of skin-to-skin contact and analysis of factors linked to failure to breastfeed within 2 hours after birth. Breastfeed Med. 2016;11:126-32. https://doi.org/10.1089/bfm.2015.0160

18. Lau Y, Tha PH, Ho-Lim SST, Wong LY, Lim PI, Nurfarah BZMC, et al. An analysis of the effects of intrapartum factors, neonatal characteristics, and skin-to-skin contact on early breastfeeding initiation. Matern Child Nutr. 2018;14(1). https://doi.org/10.1111/mcn.12492

19. Elharmeel SM, Chaudhary Y, Tan S, Scheermeyer E, Hanafy A, van Driel ML. Surgical repair of spontaneous perineal tears that occur during childbirth versus no intervention. Cochrane Database Syst Rev. 2011;8: CD008534. https://doi.org/10.1002/14651858.cd008534.pub2

20. Khadivzadeh T, Karimi A. The effects of post-birth mother-infant skin to skin contact on first breastfeeding. Iran J Nurs Midwifery Res (Online) [Internet]. 2009 [cited 2017 Oct 27]; 14(3):111-6. Available from: http://ijnmr.mui.ac.ir/index.php/ijnmr/article/view/94/94.

21. Vila-Candel R, Duke K, Soriano-Vidal FJ, Castro-Sánchez E. Effect of early skin-to-skin mother-infant contact in the maintenance of exclusive breastfeeding: experience in a health department in Spain. J Hum Lact. 2017;34(2):304-312. https://doi.org/10.1177/0890334416676469

22. Sharma A. Efficacy of early skin-to-skin contact on the rate of exclusive breastfeeding in term neonates: a randomized controlled trial. Afr Health Sci. 2016;16(3):790. https://doi.org/10.4314/ahs.v16i3.20 